\author{
Military Technical College \\ Kobry El-Kobbah, \\ Cairo, Egypt
}

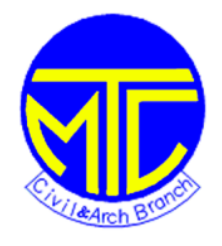

\section{Bearing Capacity of Footings Resting on Soft Clay Reinforced by Columnar Elements: Experimental Study}

\author{
By \\ .
}

Magdy Maraie ${ }^{1}$

Basuony El-Garhy ${ }^{2}$

Abdel- Fattah Youssef ${ }^{3}$
\end{abstract}

$8^{\text {th }}$ International Conference on Civil and Architecture Engineering ICCAE-8-2010 


\section{INTRODUCTION}

Soil improvement is a technique aimed to improve the engineering properties of soil, become a part of many present day civil engineering projects because of the increasing need to utilize marginal site and because many soils can be made into useful construction materials if property treated.

Techniques available for soft clay improvement are still being developed. Existing processes for other soil types are also being adopted for use with soft clays. Experience indicates clearly that the 'design' aspect of soil improvement is not at all satisfactory, and field trials are generally necessary to ascertain the improvements to be achieved by the adoption of a particular method. There is certainly ample scope for future research and development on the subject. (Brand and Brenner 1981) [1].

Several researchers have worked on theoretical, experimental and field study on behavior of sand and stone columns to develop design guidelines for soft soil stiffned with columnar elements such as sand and stone.

Hughes and Withers (1974) [2]. performed pioneering laboratory studies of sand columns within a cylindrical chamber containing soft clay, and used radiography to track the deformations occurring within and outside the column. They found that the cylindrical cavity expansion theory (CCET) represented the measured column behavior very well, and proposed an approximate formula to calculate the ultimate bearing capacity of soft soil reinforced with granular soil column.

Das (1989) [3] presented laboratory model tests results for the ultimate bearing capacity of shallow rectangular foundations supported by granular columns made in weak clay. ( $\mathrm{Ar}=100 \%$, the ratio of cross sectional area of total columnar elements to the area of footing). An approximate relationship for the ultimate bearing capacity of rectangular foundations is given

Shankar and Shroff (1997) [4] conducted experimental studies to study the effect of pattern of installation of stone columns and showed that triangular pattern seems to be optimum and rational.

Mitra and Chatopadhyay (1999) [5] studied the effect of different factors influencing the capacity of stone column improved ground from the available literature and showed that in the case of columns failing by bulging the critical length is about 3 to 5 times the stone column diameter.

Mitchell and Huber (1985) [6] compared the field performance of stone columns with the predictions by finite element analysis and reported that the agreement was generally good.

Saha et al (2000) [7] studied the load response behavior of stone columns in soft soil environment by using a finite element software package (ANSYS). The parameters 
studied are the variation of lateral deformation, lateral pressure and vertical stress with depth for various intensity of loading. The results of computer aided numerical solutions are presented in the form of non-dimensional quantities.

Madhav (2000)[8] presented an overview of recent contributions for the analysis and design of stone columns. Different equations available in the literature for finding bearing capacity and settlement of stone column improved ground have also being given.

Ambily and Gandhi (2004) [9] presented experimental studies to evaluate the behaviour of stone column by varying spacing, shear strength of soft clay, moisture content etc. The results obtained are analysed using the finite element package PLAXIS.

Bowles (1997) [10] stated that there is no theoretical procedure for predicting the combined improvement obtained in the composite system of soil reinforced with granular soil column.

Hindi et al. (2003) [11] stated that for the composite system of soft soil reinforced with sand column, the lateral pressure from the surrounding soft soil develop the confining pressure around the sand column, Rankine's earth pressure theory used to predict the ultimate lateral confining pressure

Sivakumar et al (2007) [12] presented study involved a series of laboratory model tests on a consolidated clay bed, using transparent material with 'clay like' properties. The tests, probably for the first time, have permitted visual examination of the behaviour of granular columns during the loading process. They show that significant deformation in the form of bulging occurs in long columns. 


\section{EXPERIMENTAL PROGRAM}

The experimental program consists of thirty three experiments. All the tested columns have a constant length of columns equal $20 \mathrm{~cm}$. The detailed experimental program is shown in Table 1. Each column acts within a cylindrical cell with a diameter of influence denoted by de. Spacing between columns is selected where no overlapping or minimum overlapping between cylindrical cells.

Table 1: Experimental program

\begin{tabular}{|c|c|c|c|c|c|}
\hline $\begin{array}{l}\text { Test } \\
\text { No. }\end{array}$ & $\begin{array}{c}\text { Footing } \\
\text { Dimensio } \\
\text { ns } \\
(\mathbf{c m})\end{array}$ & $\begin{array}{l}\text { Column } \\
\text { S } \\
\text { Material }\end{array}$ & $\begin{array}{l}\text { No. of } \\
\text { Colum } \\
\text { ns }\end{array}$ & $\begin{array}{c}\text { Column } \\
\text { s } \\
\text { Diamete } \\
\mathbf{r} \\
(\mathrm{cm})\end{array}$ & $\begin{array}{c}\text { No. } \\
\text { of } \\
\text { Tests }\end{array}$ \\
\hline 1 & \multirow[b]{2}{*}{$10 \times 10$} & \multirow[b]{2}{*}{ Sand } & without & - & \multirow[b]{2}{*}{10} \\
\hline $2-10$ & & & $1,4,9$ & $\begin{array}{c}1,1.6 \\
2.2\end{array}$ & \\
\hline 11 & \multirow[b]{2}{*}{$10 \times 15$} & \multirow[b]{2}{*}{ Sand } & without & - & \multirow[b]{2}{*}{10} \\
\hline $12-20$ & & & $1,4,9$ & $\begin{array}{c}1,1.6, \\
2.2\end{array}$ & \\
\hline 21 & \multirow[b]{2}{*}{$10 \times 20$} & \multirow[b]{2}{*}{ Sand } & without & - & \multirow[b]{2}{*}{10} \\
\hline $22-30$ & & & $1,4,9$ & $\begin{array}{c}1,1.6 \\
2.2\end{array}$ & \\
\hline $31-33$ & $10 \times 10$ & stone & $1,4,9$ & 2.2 & 3 \\
\hline
\end{tabular}

\section{SOFT CLAY PREPARATION}

A quantity of soft soil is taken from a site under construction, soil drying in oven for 24 hours at temperature from $\left(105-110^{\circ}\right)$, Clay soil used was passing from sieve No. $200(0.074 \mathrm{~mm})$, Clay soil stored in plastic barrels court closures.

The dried and pulverized clay sample is mixed with a quantity of water to achieve a water content of $41 \%( \pm 0.5 \%)$ (Mechanical mixer with special arm is used). Clay soil placed in the mould (diameter $57 \mathrm{~cm}$., height $45 \mathrm{~cm}$ ) on layers (each layer $5 \mathrm{~cm}$ height) and compacted by compaction device for 50 blows. The proposed height of soft clay in the mould (tank) is $30 \mathrm{~cm}$. Mould kept covered for 24 hours in order to achieve uniform consistency. After 24 hours of hydration, the soil is checked for water content and tests to determine properties of the prepared soft clay are performed (i.e., water content, liquid limit, plastic limit, direct shear test and triaxial test). Table 2 shows the properties of used soft clay. 
The mould covered with plastic and steel plate $(1 \mathrm{~cm})$ to preserve the water content of the soft clay. Care is taken to avoid the entrapped air by tapping the clay layers

After finishing the test on soft clay in the mould, the soft clay reused for preparing another sample using the previous procedures.

Table 2: Properties of used soil

\begin{tabular}{|c|c|}
\hline Water content & $41 \%( \pm 0.5 \%)$ \\
\hline Bulk density & $1.73 \mathrm{gm} / \mathrm{cm}^{3}$ \\
\hline Liquid limit (LL) & $42 \%$ \\
\hline Plastic limit (PL) & $24 \%$ \\
\hline Consistency index (Ic) & $6 \%$ \\
\hline Cohesion (c) & $0.11 \mathrm{~kg} / \mathrm{cm}^{2}$ \\
\hline Modulus of elasticity (Es) & $6 \mathrm{~kg} / \mathrm{cm}^{2}$ \\
\hline
\end{tabular}

\subsection{Columns Elements Properties}

The materials of column used in the experimental program to improve soft clay are sand, and stone. Table 3 shows the properties of columns material.

Sieve analysis test was performed on a sample of sand; Sand is classified as poorly graded sand (PS) according to united soil classification system (USCS).

Sieve analysis test was performed on a sample of stone; Stone is classified as poorly graded stone (PS) according to united soil classification system (USCS).

Table 3: Properties of columns materials

\begin{tabular}{|c|c|c|}
\hline Material & Sand & Stone \\
\hline Cohesion c $\left(\mathrm{kg} / \mathrm{cm}^{2}\right)$ & 0.0 & 0.0 \\
\hline $\begin{array}{c}\text { Angle of internal } \\
\text { friction } \varnothing\end{array}$ & $36^{\circ}$ & $42.5^{\circ}$ \\
\hline $\begin{array}{c}\text { Bulk density }\left(\gamma_{\mathrm{b}}\right) \\
\left(\mathrm{gm} / \mathrm{cm}^{3}\right)\end{array}$ & 1.751 & 1.821 \\
\hline
\end{tabular}

\section{MODEL COMPONENTS AND TEST PROCEDURE}

The following sections present the detailed description of the model components (i.e., tested soil, loading frame, and measuring devices). 


\subsection{Footing Shape}

For experimental work, three models of footings $(10 \times 10 \mathrm{~cm}, 10 \times 15 \mathrm{~cm}$, and $10 \times 20 \mathrm{~cm})$ are made of beech wood, steel plate $(6 \times 6 \mathrm{~cm})$ is placed on the top of footing to translate the load from the piston to wood footing.

\subsection{Loading Frame}

Figure 1 shows the mould components including loading frame, tank, measuring devices, loading jack and footing model. The main parts of the frame are standard I beam and channels which designed to translate load.
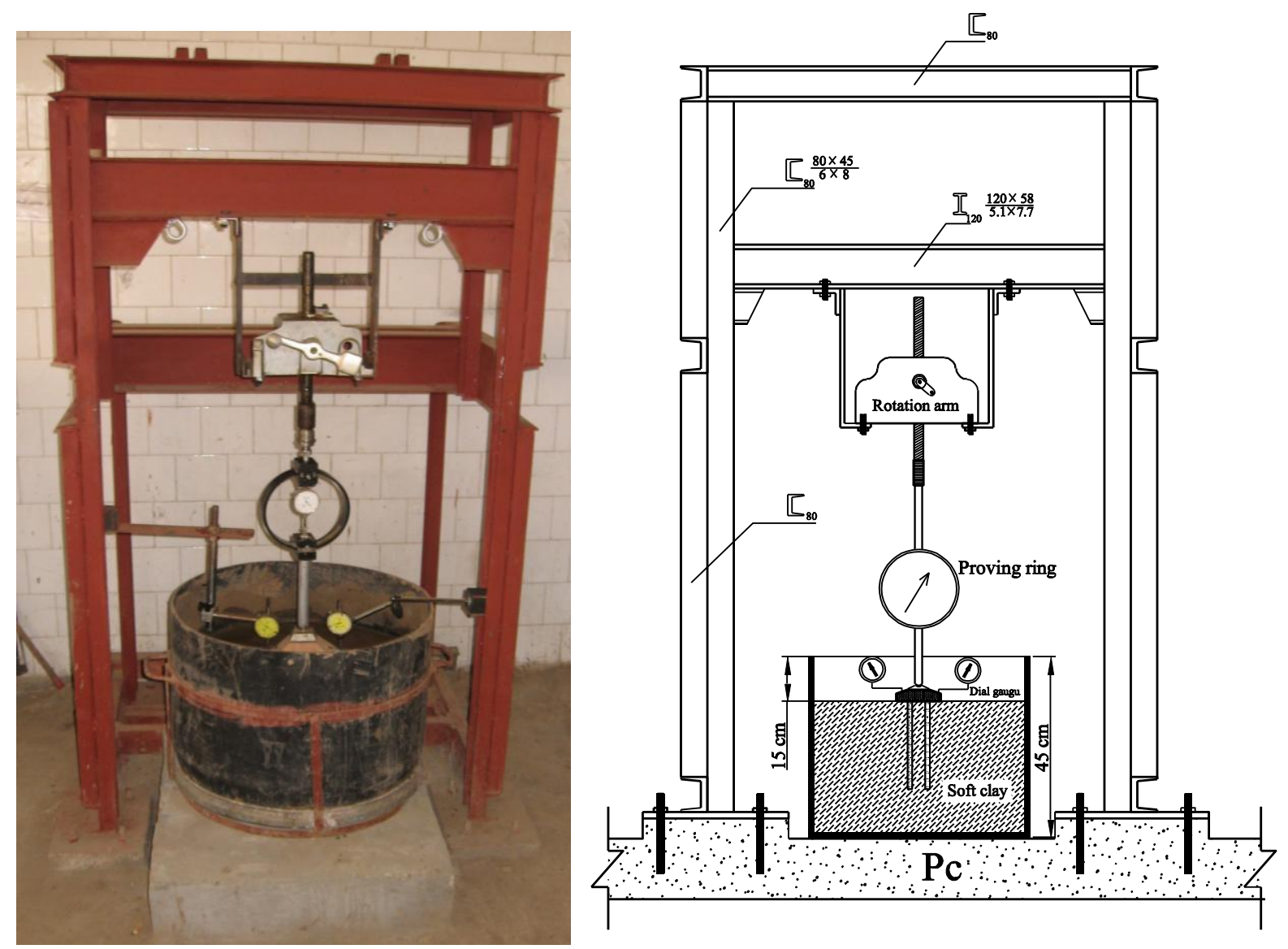

Figure 1. Photo shows the mould components

\subsection{Measuring Devices}

Calibrated proving ring of $450 \mathrm{~kg}$ is used in the tests. Dial gauge of $0.01 \mathrm{~mm}$ accuracy and total travel of $25 \mathrm{~mm}$ are used for settlement measurements. 


\subsection{Tank}

The tank is a half of PVC (container) $0.6 \mathrm{~cm}$ wall thickness, $57 \mathrm{~cm}$ inner diameter and $45 \mathrm{~cm}$ height. It is designed to accommodate the footing of variable width so that the tank boundaries exert minimum effects on the stresses and strains developed in the soil. The tank is housed inside a rigid steel frame as shown in Figure 2.
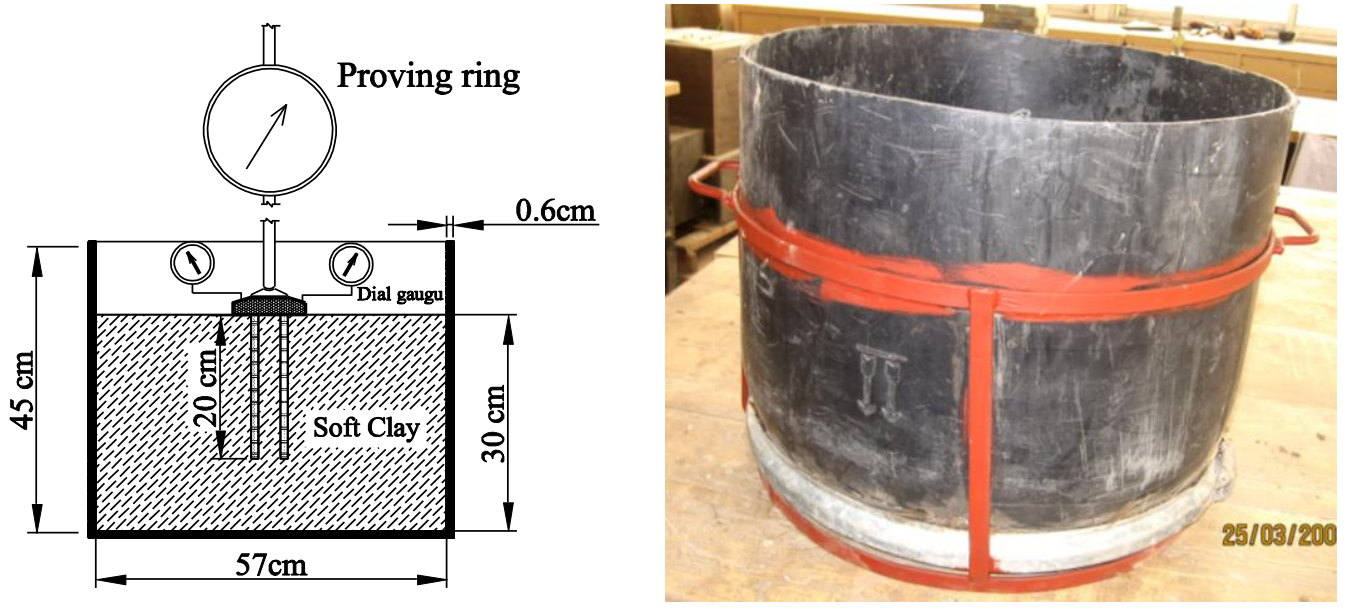

Figure 2. Sec. Elevation and photo shows the tank

\subsection{Test Procedure}

The following steps are used in the process of columns installation

Template is manufactured from wood to assist in columns installation vertically in it's locations, a hollow pipe (casing) with the required diameter is driven into the soil to the required depth $(20 \mathrm{~cm})$, (There is a head with arm inside the pipe, the diameter of the head equal to the inner diameter of the pipe), removing the head from the pipe.

Withdraw the using pipe and placing sand at the same time. For each $4 \mathrm{~cm}$, a hammer is used to compact the sand as shown in Figure 3, repeated, the process up to the end of the column. 


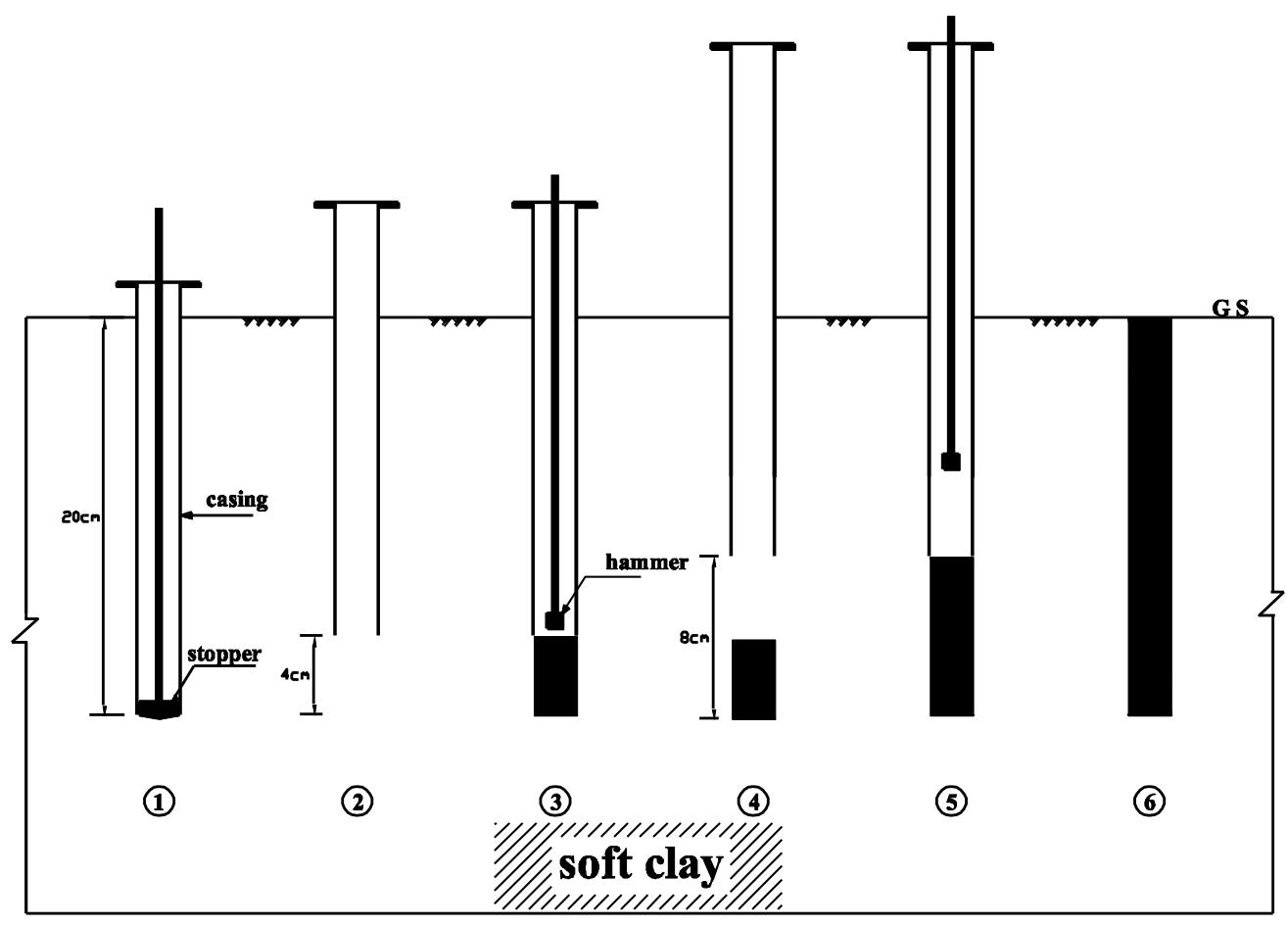

Figure 3. Steps of column installation

\subsection{Spacing between Columns}

Each column acts within a cylindrical cell with a diameter of influence denoted by $\boldsymbol{d}_{\mathrm{e}}$. (Shahu 2000) [13].

$$
d_{e}=\sqrt{\frac{4 L B}{m \pi}},
$$

Where $\mathrm{L}$ and $\mathrm{B}$ are the dimensions of footing, $\mathrm{m}$ is the number of columns. The calculated effective diameter is used to determine the spacing between columns. Spacing between columns is selected where no overlapping or minimum overlapping between cylindrical cells. Figure 4 shows columns configuration below footing $(10 \times 10 \mathrm{~cm})$
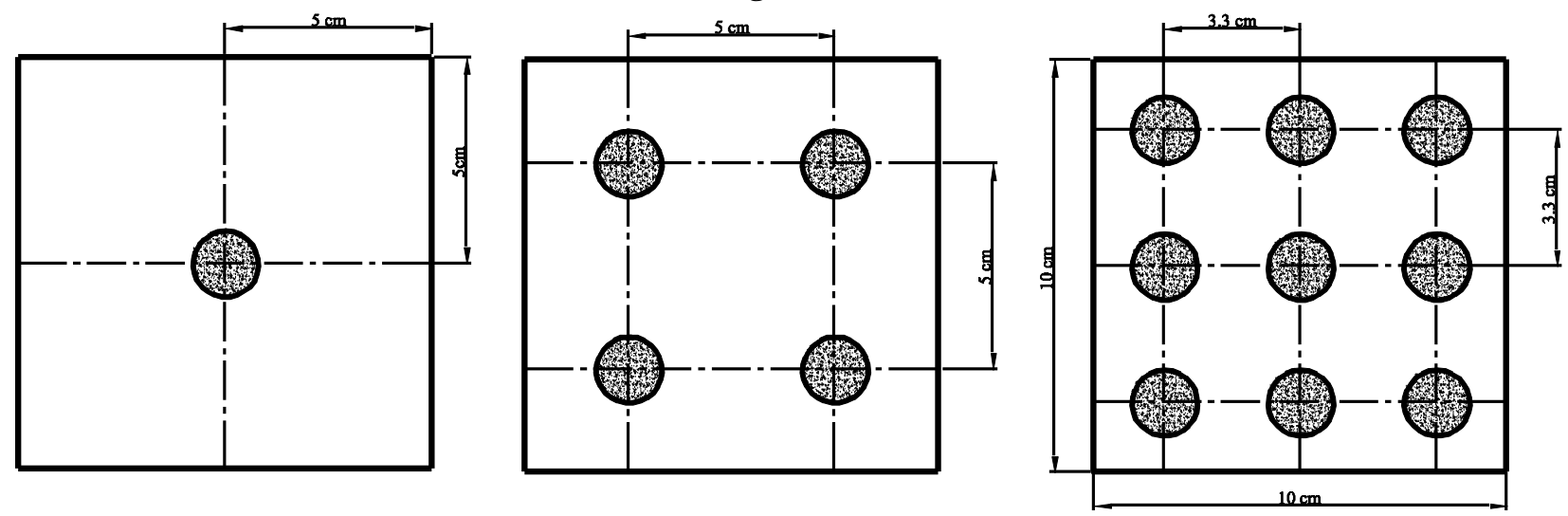

Figure 4. Columns configuration below footing $(10 \times 10 \mathrm{~cm})$ 


\section{ANALYSIS OF EXPERIMENTAL RESULTS}

The experimental results of load deflection curves are discussion. In this part the following points will be covered:

\subsection{Effect of the Sand Column Diameter and Number}

The ultimate load $(\mathrm{Pu})$ is defined as the load at $25.0 \mathrm{~mm}$ settlement as recommended by Bowels (1996) [14].

Figures 5-7. show the relationships between load $(\mathrm{kg})$ and settlement $(\mathrm{mm})$, for $10 \times 10 \mathrm{~cm}$ footing at different number of sand columns (i.e., 1, 4 and 9) and for different diameter of columnar elements (i.e., 1.0, 1.6 and $2.2 \mathrm{~cm}$ ). The following observation may be drawn:

At $25 \mathrm{~mm}$ settlement (i.e., at ultimate load), the load increases as the diameter and number of sand columns increases.

The $\%$ of load increase due to the increase of columns number and columns diameter can be calculated from the following Eq.(1) And presented in Table 4.

$$
\% \text { of load increase }=\frac{\text { load of treated case }- \text { load of untreated case }}{\text { load of untreated case }} \times 100
$$

Figure 8 . shows the effect of columns number on the \% load increase beneath $(10 \times 10 \mathrm{~cm})$ footing at $25 \mathrm{~mm}$ settlement

Figure 9. shows the effect of columns diameter on the $\%$ load increase beneath $10 \times 10 \mathrm{~cm}$ footing at $25 \mathrm{~mm}$ settlement.

Table 4. The \% of load increase due to the increase of columns diameter and columns number beneath $10 \times 10 \mathrm{~cm}$ footing

\begin{tabular}{|c|c|c|c|}
\hline \multirow{2}{*}{$\begin{array}{c}\text { No. of } \\
\text { columns }\end{array}$} & \multirow{2}{*}{$\begin{array}{c}\text { Column } \\
\text { diameter } \\
(\mathrm{cm})\end{array}$} & \multicolumn{2}{|c|}{ At $25 \mathrm{~mm}$ settlement } \\
\cline { 3 - 4 } & load & $\begin{array}{c}\text { \% of load } \\
\text { increase }\end{array}$ \\
\hline \multicolumn{2}{|c|}{$\begin{array}{c}\text { Without columns } \\
\text { (untreated) }\end{array}$} & 20.2 & 0.0 \\
\hline \multirow{4}{*}{1} & 1.0 & 22.8 & 12.871 \\
\cline { 2 - 4 } & 1.6 & 25 & 23.762 \\
\cline { 2 - 4 } & 2.2 & 32.2 & 59.406 \\
\hline \multirow{4}{*}{4} & 1.0 & 27.2 & 34.653 \\
\cline { 2 - 4 } & 1.6 & 36.8 & 82.178 \\
\hline \multirow{3}{*}{9} & 2.2 & 51 & 152.48 \\
\cline { 2 - 4 } & 1.0 & 36.6 & 81.188 \\
\cline { 2 - 4 } & 1.6 & 57 & 182.18 \\
\hline \multirow{2}{*}{} & 2.2 & 74.3 & 267.82 \\
\hline
\end{tabular}




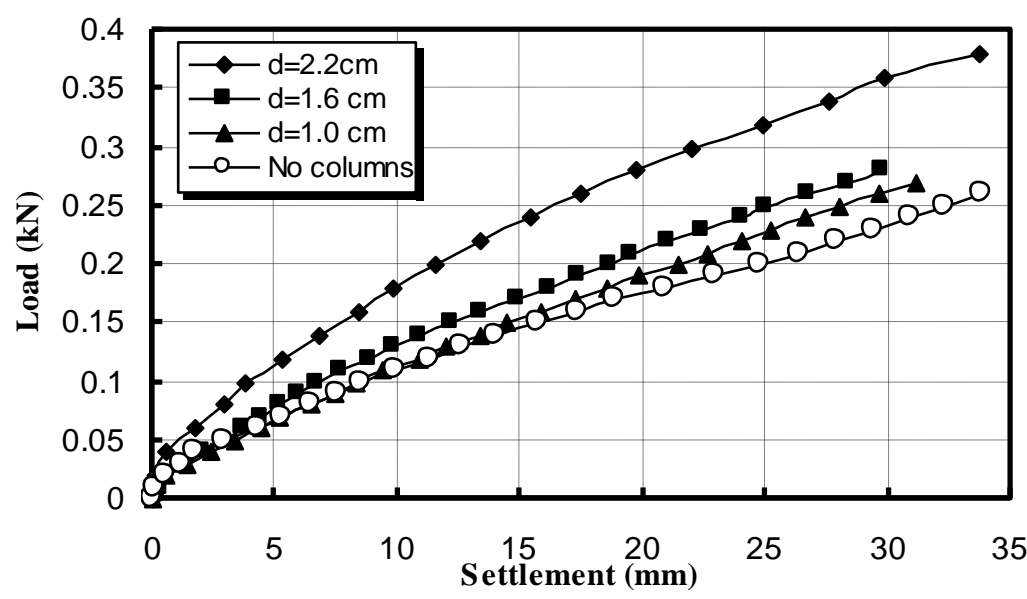

Figure 5. Load settlement curves for $10 \times 10 \mathrm{~cm}$ footing at different diameters of sand column ( 1 column)

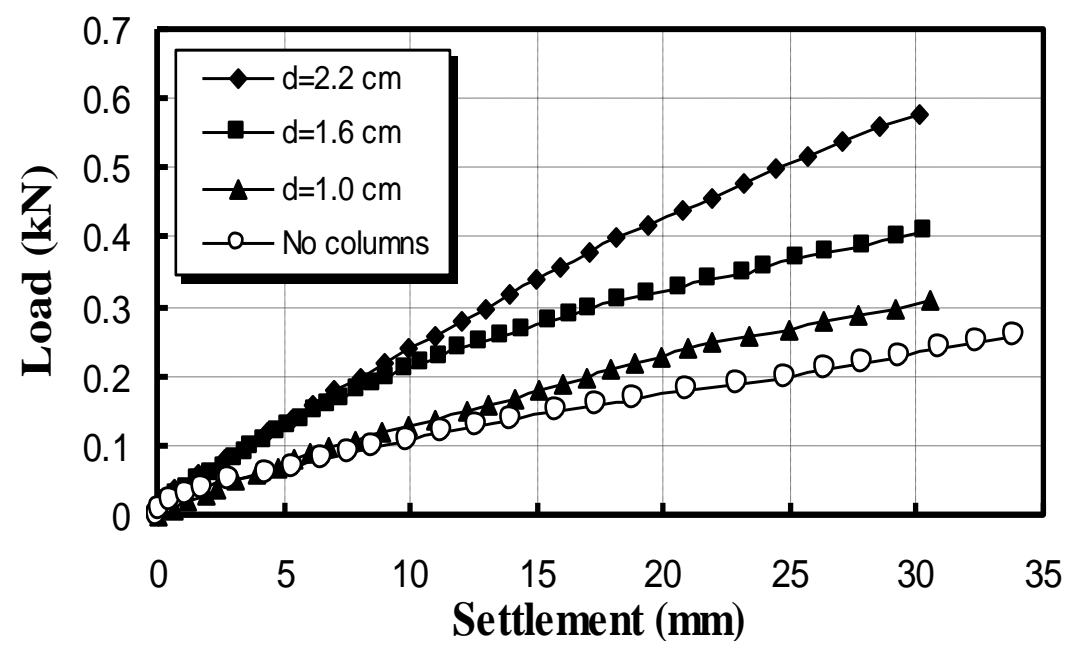

Figure 6. Load settlement curves for $10 \times 10 \mathrm{~cm}$ footing at different diameters of sand column ( 4 columns) 


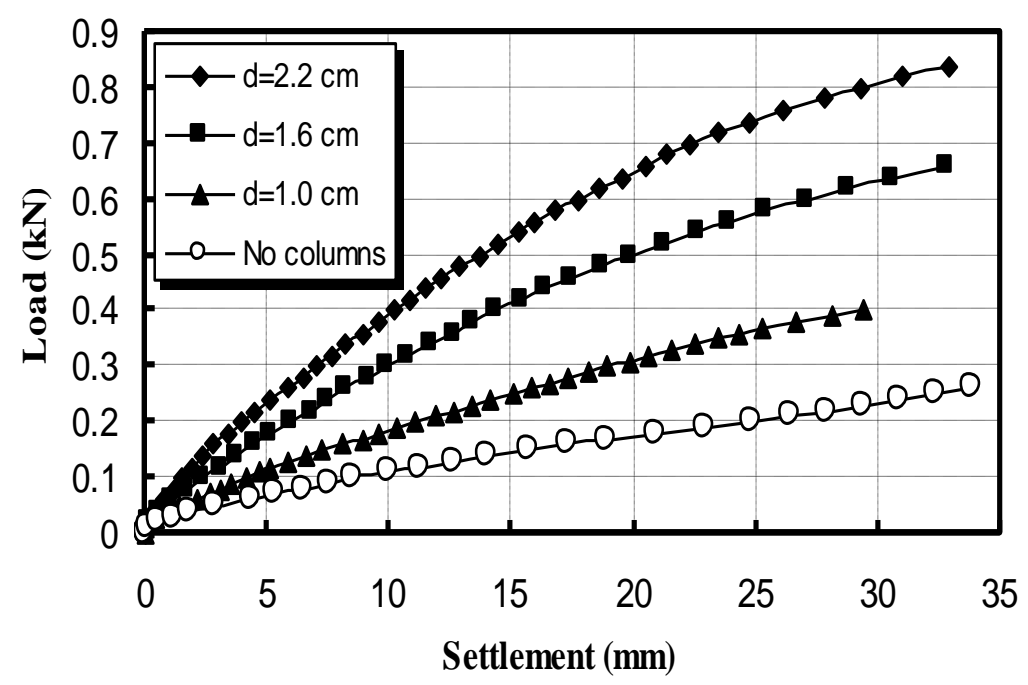

Figure 7. Load settlement curves for $10 \times 10 \mathrm{~cm}$ footing at different diameters of sand column ( 9 columns)

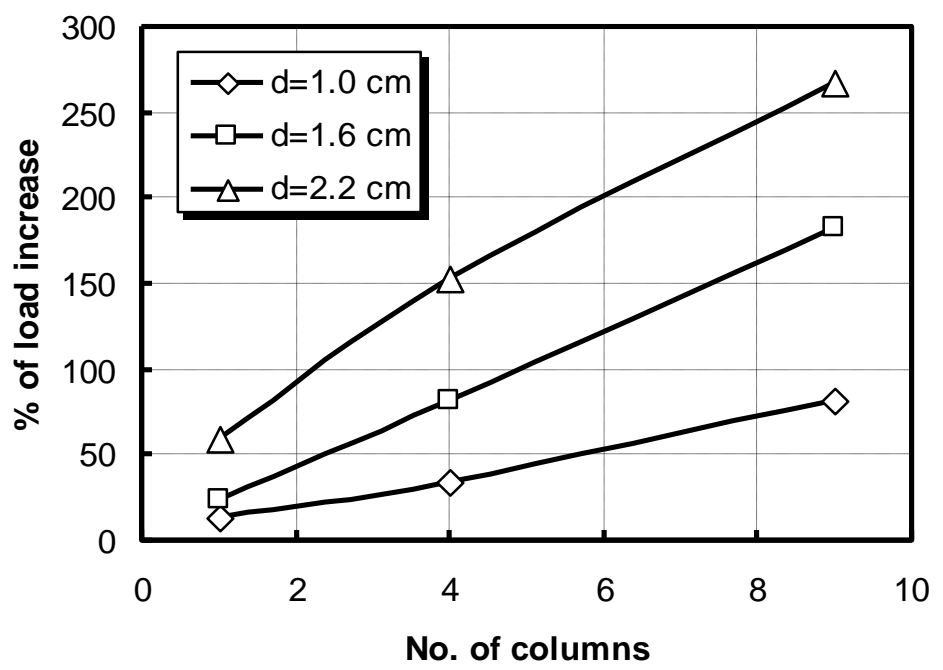

Figure 8. Effect of columns number on the \% of load increase beneath $10 \times 10 \mathrm{~cm}$ footing at $25 \mathrm{~mm}$ settlement 


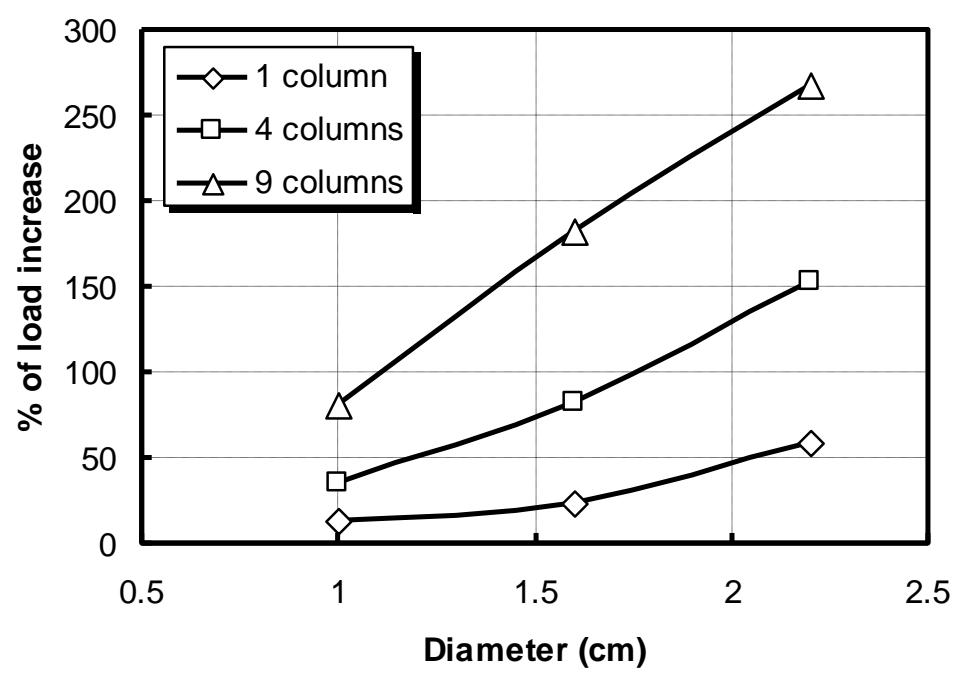

Figure 9. Effect of columns diameter on the \% of load increase beneath $10 \times 10$

\subsection{Effect of Area Ratio} cm footing at $25 \mathrm{~mm}$ settlement

Area ratio (Ar) is the ratio of cross sectional area of total columnar elements to the area of footing:

$$
A_{r}=\frac{A_{c}}{A_{f}}
$$

Where: $A_{c}=$ cross section area of columnar elements, $\quad A_{f}=$ area of footing

Figure 10. shows the relationship between load $(\mathrm{kg})$ and area ratio for footings $10 \times 10 \mathrm{~cm}, 10 \times 15 \mathrm{~cm}$ and $10 \times 20 \mathrm{~cm}$, respectively for ultimate load.

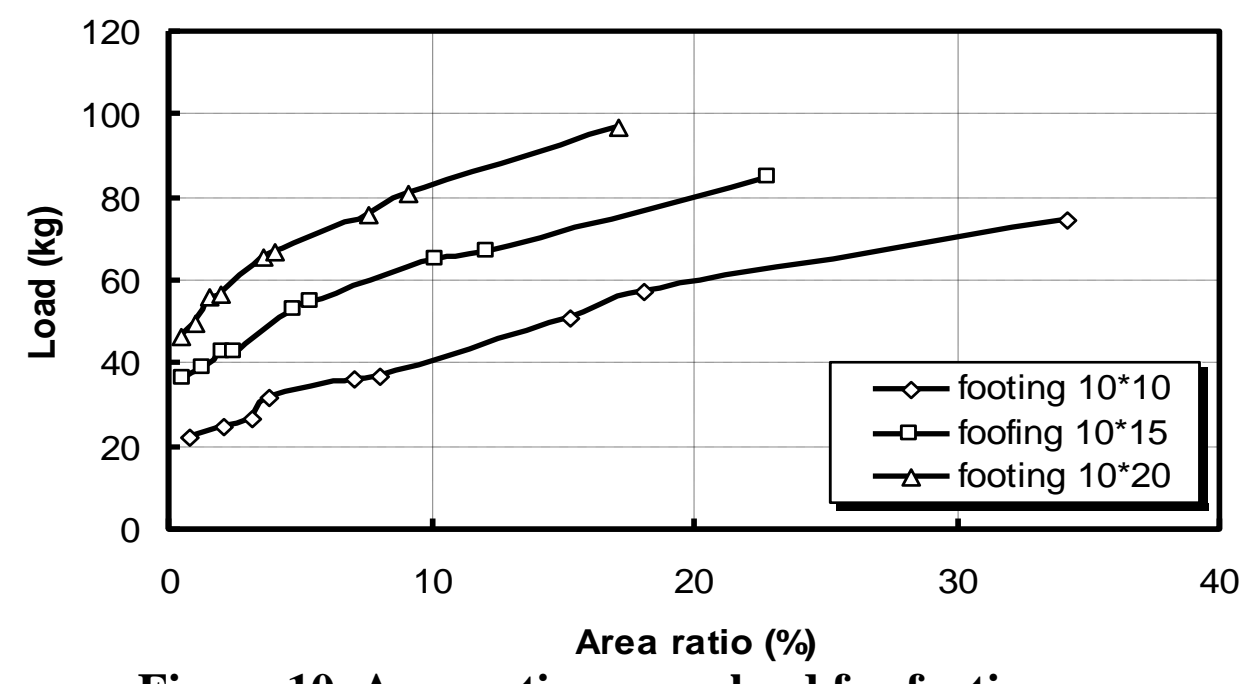

Figure 10. Area ratio versus load for footings 


\subsection{Effect of Footing Dimensions (L/B Ratio)}

From Figure 11, it is noticed that the ultimate load increase as the footing dimension increase, columns diameters increases and as the number of columns increases

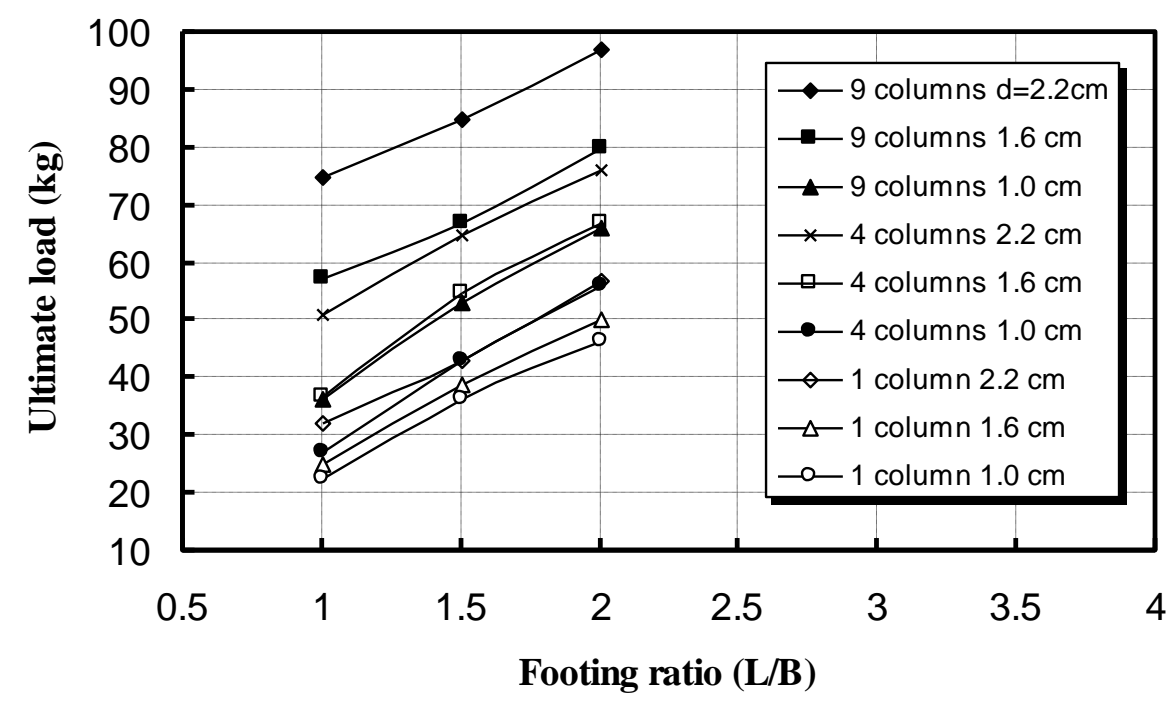

Figure 11. Footing ratio curve

\subsection{Effect of Different Column Material}

The effect of different materials is discussed in the following. Figures indicate the relation between load $(\mathrm{kg})$ and settlement $(\mathrm{mm})$ for footing $(10 \times 10)$ (with one columns $2.2 \mathrm{~cm}$ diameter), and footing $(10 \times 10)$ with one column $(2.2 \mathrm{~cm}$ diameter) sand and without any columns as a reference (guide).

\subsubsection{Effect of Stone Column}

Figure (12) shows the relationships between load $(\mathrm{kg})$ and settlement $(\mathrm{mm})$ for stone column and sand column for constant diameter $(2.2 \mathrm{~cm})$.

From Fig. (11) at $25 \mathrm{~mm}$ settlement, using stone column causes an increase in the foundation load compared to sand column with the same diameter and number of columns. 


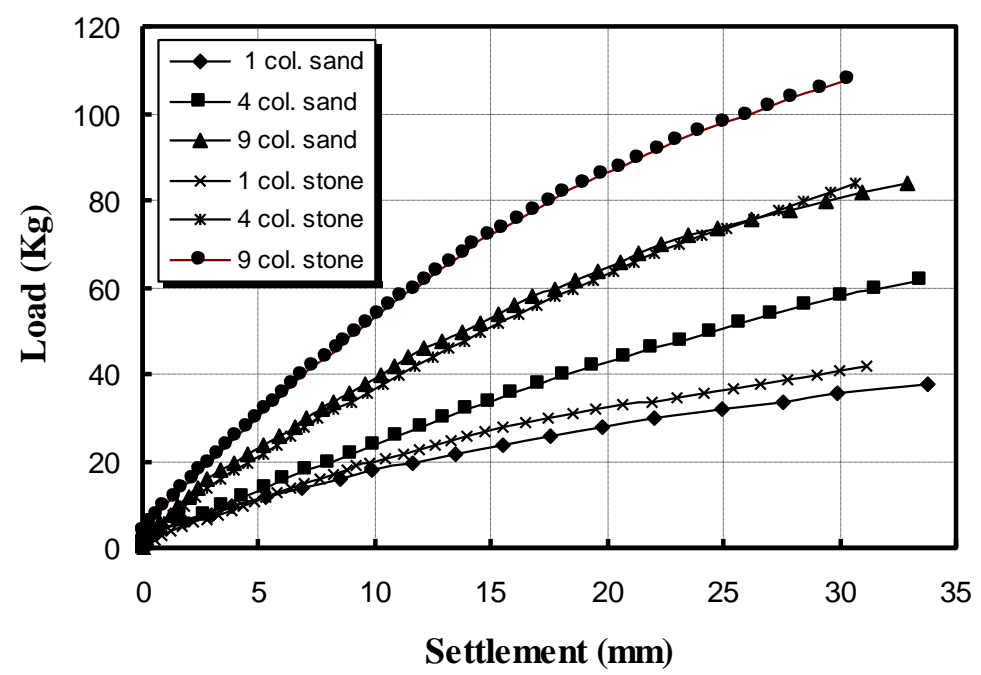

Fig. 12 Load- settlement curves for sand and stone column $(10 \times 10$ footing, No. of columns $=1,4$ and $9, d=2.2 \mathrm{~cm})$

Figure (13) shows the relationships between area ratio (\%) load $(\mathrm{kg})$ at $25 \mathrm{~mm}$ settlement for stone column and sand column for constant diameter $(2.2 \mathrm{~cm})$.

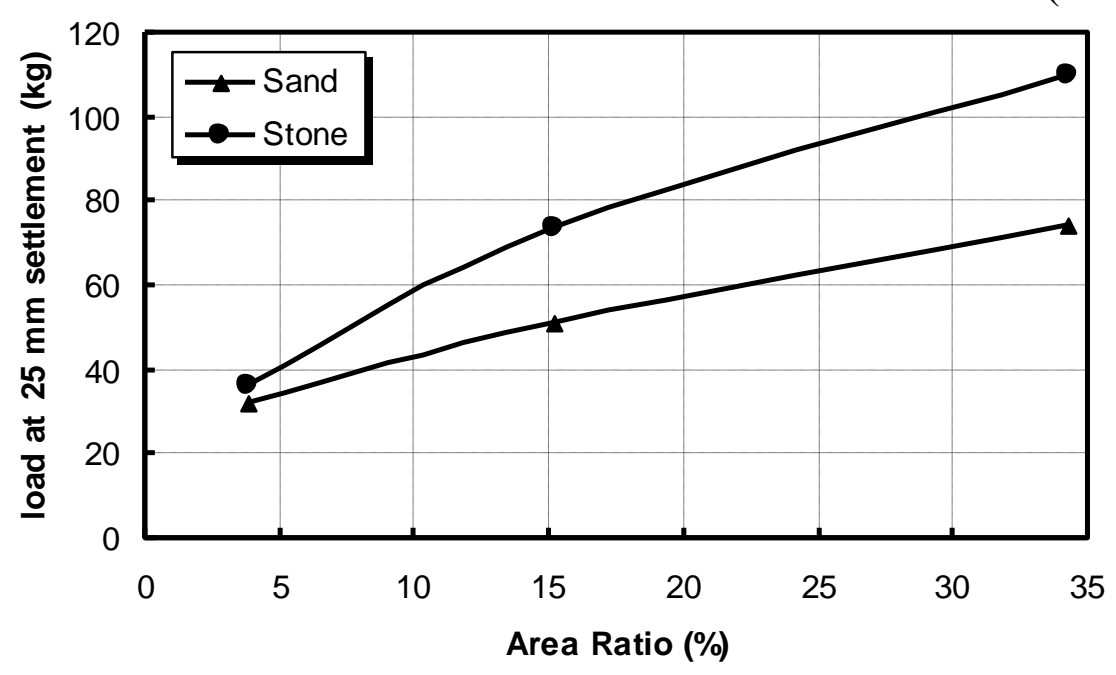

Fig. 13 Area ratio versus load curves for sand and stone column

\section{CONCLUSIONS}

The experimental work presented in this research is performed to study the performance of shallow foundation with different dimensions resting on soft clay reinforced by columnar elements. Two materials for column elements are tested. These are: sand, and stone. Different numbers and diameters of columns are tested to study the effect of columns number and diameters on the load settlement curve.

The following conclusions can be drawn from the study.

1. At $25 \mathrm{~mm}$ settlement, the increase in columns diameters causes an increase in foundation loads. 
2- At $25 \mathrm{~mm}$ settlement, the effect of column diameter on foundation load increases as the number of columns increases.

3. At $25 \mathrm{~mm}$ settlement, using stone column causes an increase in the foundation load by compared to sand column with the same diameter and number of columns.

\section{REFERENCES}

[1] Brand E. W. and Brenner R. P. (1981), Soft clay Engineering. Elsevier scientific publishing company

[2] Hughes J. M. O. and Withers N. J. (1974), Reinforcing of soft cohesive soils with stone columns. Ground Engineering, 7(3): 42-49.

[3] Das B. M., (1989), Bearing Capacity of Shallow Foundation on Granular Column in Weak Clay. Foundation Engineering: Current Principles and Practices, ASCE, Vol. 2, pp. 1252-1263.

[4] Sankar, K. and Shroff, A.V. (1997). Experimental Study on Floated Stone Column in Soft Kaolinite Clay. Proc. of Indian Geotechnical Conference held at Vadodara., 265268.

[5] Mitra, S. and Chathpadhyay, B.C. (1999). Stone Columns and Design Limitations. Proc. of Indian Geotechnical Conference held at Culcutta , 201 - 205.

[6] Mitchel, J.K. and Huber, T.R. (1985). Performance of a Stone Column Foundation. Journal of Geotechnical Engineering, Vol. 111, No. 2, ASCE.

[7] Saha, S., Saha, S. and Roy, A. (2000). Analysis of Stone Column in Soft Ground, Indian Geotechnical Conference 2000 held at Bombay, 297 - 300.

[8] Madhav, M.R.(2000).Granular Piles - Recent Contributions. A short term course on Ground Improvement and Deep foundations held at IIT Madras, Dec 2000, MRM1 MRM38

[9] A.P. Ambily and S.R. Gandhi (2004), Experimental and Theoretical Evaluation of One Column in Soft Clay, ICGGE-2004

[10] Bowles J. E. (1997), Foundation analysis and design, Fifth Edition. The McGrowHill Companies, Inc.

[11] Abd El-Rahman O. Hendi, Abd El- Aziz R. Bondok, Mona B. Anwar. (2003), Bearing Capacity of Reinforced Soft Soil. Tenth International Colloquium on Structural and Geotechnical Engineering, April 22-24, Cairo.

[12] Sivakumar V., D Glynn, J Black, J McNeill, (2007), A laboratory model study of the performance of vibrated stone columns in soft clay. Proceeding of the 14th European Conference on soil mechanics and Geotechnical Engineering, Madrid, Spain, 24-27 September

[13] Shahu J. T., Madhav M. R. and Hayashi S. (2000), Analysis of soft groundgranular pile- granular mat system. Computers and Geotechnics. 27, 45-62

[14] Bowles J. E. (1996), Foundation analysis and design, Fourth Edition. The McGrow-Hill Companies, Inc. 